\title{
Editor's Introduction: Canons, Classics and Publics
}

\author{
Lawrence T. Nichols ${ }^{1}$
}

Published online: 8 August 2015

(C) Springer Science+Business Media New York 2015

In this issue we offer a rich variety of papers that share some common foci, especially intellectual and historical traditions and relations with external groups. Some articles address very immediate issues, while others provide an historical perspective that seeks to link past events to contemporary work in sociology. There is also an international dimension, with a particular focus on Russia.

We begin with Neil Smelser's insightful analysis of sources of unity and disunity in the field of sociology. Consistent with his longstanding interest in the process of differentiation (which includes both difference and integration), Smelser probes the factors that operate to bring us together or to pull us apart. Although the tone is dispassionate, the discussion embodies Smelser's deep concern for the well-being of his discipline. For him, as it was for his mentor, Talcott Parsons, sociology has always been an affair of the heart.

Dmitri Shalin's article is likewise oriented toward both unity and disunity, but with a particular focus on competing constructions of the work of George Herbert Mead. If Mead's work is now generally regarded as canonical, how did that come to be? Moreover, who "speaks for Mead," and who should be regarded as the most legitimate interpreter of his writings? The discussion brings to mind a remark by Everett $\mathrm{C}$. Hughes, years ago, while he was at Boston College. In challenging a proposed reading list of theoretical works (which I had helped to draft), Hughes demanded, "Who defines the canon?"

Pavel Sorokin begins by noting that, in the professional literature, the image of "Russian sociology" remains "fragmentary and incomplete." He therefore attempts to identify the basic features of sociology in Russia, to demonstrate its fundamental continuity over nearly two centuries, and to reveal its relevance to contemporary debates in the field. What is especially noteworthy, in his view, is that sociology in Russia has always had a deeply "public" character, in the sense that it has always been oriented primarily toward contemporary social problems (e.g., serfdom and tsarism)

Lawrence T. Nichols

Larry.Nichols@mail.wvu.edu

1 Department of Sociology and Anthropology, West Virginia University, 307 Knapp Hall, PO Box 6326, Morgantown, WV 26506, USA 
and their solution. Though highly commendable from an ethical perspective, this approach has also resulted in serious shortcomings, in particular a limited development of what Michael Burawoy calls "professional sociology."

Joshua Woods extends the discussion of public sociology by examining one particular genre of work, namely, "op-ed" essays by sociologists in prominent newspapers. He applies two contrasting lenses, pluralistic (based on Habermas's deliberative democracy) and elitist (based on Merton's "Matthew Effect"), in identifying who gets invited to produce op-ed sociology for two major liberal-oriented and one conservativeoriented paper. Woods is especially interested in the ways that status characteristics (e.g., rank, university affiliation, sex) have affected outcomes over a period of some 30 years.

Terry Wotherspoon illumines earlier efforts in "public sociology," by tracing the involvement of sociologists such as Pitirim Sorokin and Robert MacIver in a series of high-profile, national conferences on science, democracy and religion. Given the dramatic expansion of sociology in the U.S. during the 1960s, as well as its current place in higher education, it is difficult for some readers to appreciate that the field was very much at risk in earlier decades. In that historical context, invitations to sociologists to contribute a distinctive expertise side by side with prominent natural scientists (e.g., Einstein), philosophers (e.g., Bertrand Russell and John Dewey) and other celebrated intellectuals (e.g., Margaret Mead and Hannah Arendt) were an important indicator of acceptance and legitimation.

The issue concludes with Jerome Braun's assessment of the continuing relevance of the work of Hans Gerth and C. Wright Mills. His particular focus is on their jointly authored book, Character and Social Structure: The Psychology of Social Institutions, which is less well known than are some of Mills's later writings, especially The Power Elite and The Sociological Imagination. The widespread image of Mills as a conflict sociologist-indeed, a leading figure in what might be termed "the conflict turn" in the field-tends to conceal his contributions as a social psychologist with deep roots in pragmatism. Gerth, meanwhile, is remembered mainly for his work, again with Mills, that introduced the sociology of Max Weber to scholars in the U.S. Thus, how Gerth and Mills are remembered and constructed hearkens back to Shalin's discussion of definitional contests over Mead. Braun's analysis also indicates a connection between Character and Social Structure and recent work on the relations between structure and agency.

I am confident that many readers with find this set of papers both highly pinformative and highly stimulating, as I have. The issues of canons, classics and publics are perennial, and so always deserving of our reflection. 